\title{
A Review of Integrated Energy System with Power to Gas Technology
}

\author{
Shah Faisal
}

\begin{abstract}
To save excess power large scale energy storage is required to overcome the short term storage. The increasing demand of electricity and neglecting the excess energy presented the idea of Power to Gas (P2G), because gases can be stored economically for long time, while electricity cannot be stored economically for long time. P2G plays a vital role in enhancing large-scale integrated energy system in energy sector. The process of converting surplus electrical energy into gases and its planning in an integrated energy system for different purposes is significant for developing the technology. This paper reviewed the study of integrated energy system with the power to gas technology. The conversion technologies, basics, storage capacity and siting in integrated energy systems are analyzed for modeling which assesses to their suitability for applications. Coupling, aims, applications and economic analysis to enhance the performance of the system, balance the system and to offer better facilities to consumers are investigated. The large capacity of P2G system, can provide long term energy storage requirements. P2G need further research work to address the issues of cost minimization as it is very expensive technology, optimal location, economy, energy efficiency improvement and proper methodologies for integration.
\end{abstract}

Index Terms - Electrical Energy; Energy System; Integrated Energy System; Power to Gas.

\section{INTRODUCTION}

Power-to-Gas system is for storing excess energy in the form of gases by performing water electrolysis which split water into oxygen and hydrogen. Renewable energy sources (RES) are favored to decrease greenhouse gas emissions in the power generation areas but they show deficiencies due to their unbalanced and irregular nature. The power to gas system handle this uncertainty, by storing extra electricity generated when the demand is less than supply [1]. The complementary skills on daily, weekly and seasonal origin in order to consume the unstable renewable generation lead to a rise in storage capacity. The conversion of electricity into gases afford a huge quantity of storage options and connecting of different energy arcades with each other [2]. Renewable energy consuming massive energy storage and power to gas system hold this matter not only in relations of energy storage but also in terms of $\mathrm{CO}_{2}$ consumption [3]. In [4], a study led for the conceivable influence of RES together with power-to-liquid and P2G for forthcoming expectations and forecasts is observed. Grid assessment system by means of gas turbine power plants with $\mathrm{P} 2 \mathrm{G}$ system are deliberated. Power to gas system is a worthy elucidation for electric grid stability and can support in reducing the uncertainty of dispatch approaches [5].
The energy sector is very active for developing the energy market, electricity market price elasticity, decrease the cost, lessen the waste of energy, and improve the efficiency [6], [7]. Moving from conventional system to renewable energy sources which yield free and zero emission energy is the elongated period of achievement plan to lessen the emissions from fossil fuels [8], [9]. The storage of electrical energy is not possible at immense quantity and production of renewable energy is inflexible to term a potential future event and may cause instabilities of energy in the grid. Even though there is the existence of problems, but they are believed to be the energy sources of the future [8], [10]. When the amount exceeds the demand the issue of energy storage can be resolved and consuming it when the demand is greater than the amount supply. Renewable energy is in a performance of an important role to undertake the energy demand and the new goal for renewable energy will be at least $27 \%$ by 2030 . Diverse arrangements are existing to store energy but the appropriate choice depends on different features such as site, performance (efficiency, energy density, etc.) and costs [8].

IES (Integrated Energy System) is expecting to achieve the lowest and economical energy prices in the future. Conferring to end-user's necessities, it can be an auxiliary to the prevailing energy system [11], [12]. To retain and alert the challenges of future, integrated energy system model the energy setups and its integration with conversion systems such as Power-to-Gas, Power-to-Heat, Gas to Heat and Electricity, and energy storage system [13]. It is encouraged by the idea of smart and intelligent energy allocation and supervision organization and economic saving [14], [15]. The converted electricity is the fundamental of the revolution of multiple energy carriers, and progressive economic performance can be accomplished with the optimization of management and organization [16]. It needs a robust transmission grid for well energy flow without instabilities. It is an effective method across electricity, heating, cooling, gas, transportation, and water, to rise the energy system and balance the instabilities in an improved technique. For accomplishing the comprehension of the system innovative technology is required to get the paramount system. Latest communication technology is an imperative feature of information exchange. In the operation of IES energy router shows a momentous role. Energy router work as a fundamental of energy storage, generation, and energy distribution [17]. The Future Renewable Electric Energy Delivery and Management System (FREEDM) is a descriptive of IES planning. It links power system with dispersed and alternative generating bases and storage equipment [18]-[20]. 
This paper is a review of the integrated energy system with power to gas technology. Electricity is generating from many sources such as solar, hydel, wind, biomass, nuclear, coal, thermal and tidal, etc. Renewable energy is the natural source which exists easily for the generation of electricity. The excess power generation from renewable sources get wasted, to use this wasted energy, the power to gas technology is introduced. Power to gas technology converts the excess amount of energy to gas through water electrolysis and the produced gas is stored in tanks.

The remaining sections of this paper are organized as follows. Section 2 contains the modeling of the system. Section 3 demonstrated essential aspects of IES with P2G planning and the last section is the conclusion of the paper.

\section{THE MOdeling OF THE SySTEM}

\section{A. P2G Conversion System}

The conversion of electricity into gas take place in electrolyser through the process of water electrolysis. Different sorts of electrolysis process are used for conversion e.g. alkaline water electrolysis, proton exchange membrane (PEM) electrolysis, and high-temperature water electrolysis etc. The survey of International energy association shows that $35 \%$ of electricity will be generated from natural gas in the year 2030. In the electrolyser supplying electricity to electrodes perform the action of splitting the water into gaseous form. The electrolyzer is composed of electrolyte and is proficient of conducting ions and a diaphragm which is electric isolator and preserves the gas isolated to evade an ignitable mixture [1]-[3]. There are three provisions of $\mathrm{P} 2 \mathrm{G}$ installations considered at three certain sets of areas i.e. congested electrical nodes, congested gas nodes and gas terminals. The conversion technology can be any electrolyser but mostly PEM is favorable technology for P2G conversion. For Methanation process, $\mathrm{H}_{2}$ from water electrolysis process with carbon dioxide take place in Sabatier reaction $\left(\mathrm{CO}_{2}+4 \mathrm{H}_{2} \rightarrow \mathrm{CH}_{4}+4 \mathrm{H}_{2} \mathrm{O}\right)$ [3]-[5]. The efficiency of renewable energy sources (RES) conversion into gases is 54$77 \%$ [6]. Table 1. shows the characteristics of electrolyzers.

TABLE 1 CHARACTERISTICS OF ALKALINE, PEM AND HIGH-TEMPERATURE ELECTROLYZER [6]

\begin{tabular}{|c|c|c|c|}
\hline & $\begin{array}{c}\text { Alkaline } \\
\text { Electrolyzer }\end{array}$ & $\begin{array}{c}\text { PEM } \\
\text { Electrolyzer }\end{array}$ & $\begin{array}{l}\text { High-Temperature } \\
\text { Electrolyzer }\end{array}$ \\
\hline Electrolyte & $\begin{array}{c}\text { Aqueous } \\
\text { Alkaline } \\
\text { Solution }(\mathrm{KOH} \\
\text { or } \mathrm{NaOH})\end{array}$ & Solid Polymer & $\begin{array}{l}\text { Yttria-stabilized } \\
\text { zirconium oxide }\end{array}$ \\
\hline $\begin{array}{l}\text { Operation } \\
\text { Temperature }\end{array}$ & $60-80^{\circ} \mathrm{C}$ & $50-80^{\circ} \mathrm{C}$ & $700-1000^{\circ} \mathrm{C}$ \\
\hline $\begin{array}{l}\text { Operation } \\
\text { Pressure }\end{array}$ & $<30$ bar & $<30$ bar & \\
\hline Efficiency & $65-75 \%$ & $50-70 \%$ & $70 \%$ \\
\hline $\begin{array}{l}\text { Part Load } \\
\text { Range }\end{array}$ & $20-40 \%$ & $0-10 \%$ & \\
\hline Disadvantages & $\begin{array}{l}\begin{array}{c}\text { Most mature } \\
\text { technology }\end{array} \\
\text { Relatively low } \\
\text { current density }\end{array}$ & $\begin{array}{l}\text { Ability to } \\
\text { operate in part } \\
\text { load and } \\
\text { overload } \\
\text { conditions }\end{array}$ & $\begin{array}{l}\text { Can be used with } \\
\text { high-temperature } \\
\text { heat sources like } \\
\text { nuclear or } \\
\text { geothermal power } \\
\text { The need for } \\
\text { Constant operation }\end{array}$ \\
\hline
\end{tabular}

The model design of the system is on-grid and off-grid power to gas system. The on-grid system is connected with a bulky or national grid while off-grid P2G system is designed where networking with a bulky or national grid is absurd [6]. Figure 1 shows the basic model of power to gas system which comprises of four types of loads e.g. electrical load (E Load), hydrogen load (H Load), heat load (Ht Load) and natural gas load (G Load). In the water electrolysis process, the water $\left(\mathrm{H}_{2} \mathrm{O}\right)$ molecules divided into gases (Hydrogen and Oxygen) $\left(2 \mathrm{H}_{2} \mathrm{O} \rightarrow 2 \mathrm{H}_{2}+\mathrm{O}_{2}\right)$, and hydrogen is stored in a container or tank. From tank, hydrogen is added to fuel cell, Hydrogen boiler and for methanation process. The mathematical modeling of IES with $\mathrm{P} 2 \mathrm{G}$ is as below.

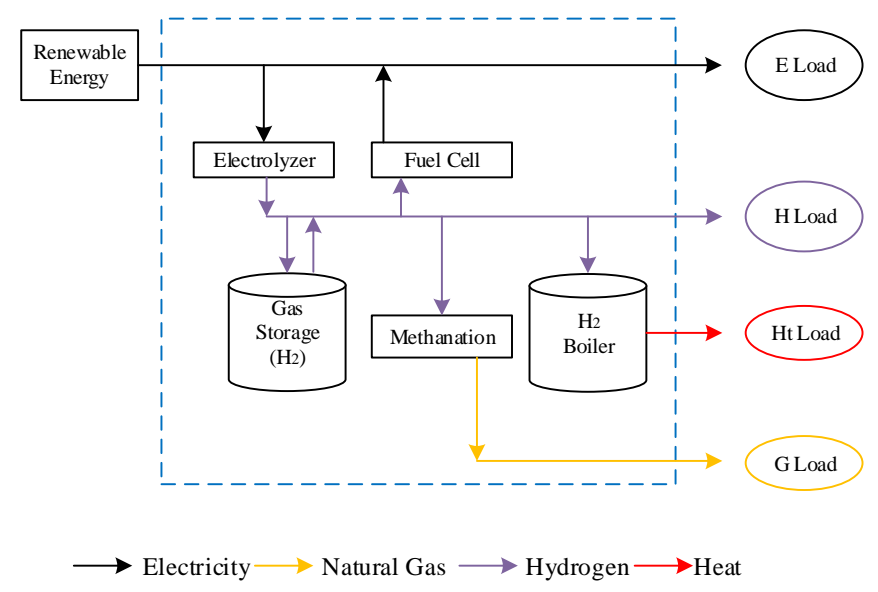

Fig. 1. Basic Infrastructure of P2G System [7]

The conversion equation of $\mathrm{P} 2 \mathrm{G}$ :

$\left\{\begin{array}{l}\mathrm{H}_{2} \mathrm{O}(\mathrm{l}) \rightarrow \mathrm{H}_{2}(\mathrm{~g})+\frac{1}{2} \mathrm{O}_{2}(\mathrm{~g}) \\ \Delta H_{298}^{o}=247.8 \mathrm{~kJ} / \mathrm{mol}\end{array}\right.$

The performance equation is:

$H y_{e l}(t)=\left\{\begin{array}{c}E_{e l}(t) \eta_{e l} \text { if } E_{e l}(t) \geq \underline{E_{e l}} \\ 0 \text { if } E_{e l}(t)<\underline{E_{e l}}\end{array}\right.$

As the efficiency decrease at low load, the electrolyzer has the minimum bounds of electricity. In methanation process Sabatier catalyst take place which converts carbon dioxide $\left(\mathrm{CO}_{2}\right)$ and hydrogen $(\mathrm{H})$ into water and methane [7]. The equation is as:

$\left\{\begin{array}{l}4 \mathrm{H}_{2}+\mathrm{CO}_{2} \rightarrow \mathrm{CH}_{4}+2 \mathrm{H}_{2} \mathrm{O} \\ \Delta \mathrm{H}_{\mathrm{R}}^{\mathrm{o}}=-165.12 \mathrm{~kJ} / \mathrm{mol}\end{array}\right.$

Hydrogen can be store, which can be utilize in peak hours and can be stored in off-peak hours. In [4], the chemical reaction which needs Hydrogen $\left(\mathrm{H}_{2}\right)$ with Carbon dioxide $\left(\mathrm{CO}_{2}\right)$ in water electrolysis for methanation is as below:

$\mathrm{CO}_{2}+4 \mathrm{H}_{2} \rightarrow \mathrm{CH}_{4}+4 \mathrm{H}_{2} \mathrm{O}$ 


\section{B. Basics of IES with P2G System}

$\mathrm{P} 2 \mathrm{G}$ is the arrangement of power and gas system converting excess electricity into gases, which can be stored and utilized economically. The basics comprise of three stages i.e. power system, electrolyzer, and gas system. The power system comprises of generation to transmission and distribution.

The power generation is the primary stage that is involved in the $\mathrm{P} 2 \mathrm{G}$ process, power generation from renewable energy sources is the paramount choice because in peak generation we can convert surplus electricity to gas in electrolyzer. The next stage is electrolysis which converts excess electricity to gases through water electrolysis. And the last stage is gas production from electricity conversion in electrolyser by water electrolysis process, and the gas can be stored in tanks for prospect utilization or for the power generation. According to a research study, the $\mathrm{P} 2 \mathrm{G}$ system can attain a $41.7 \%$ reduction of energy intake and decrease the yearly running cost of about 1.77 million dollars, related with the separation production system [8].

\section{Storage Capacity of the System}

Power to gas system attained high focus in research now a days as the excess electricity is used to produce gas. The gas is stored in storage container or tanks for future use that can be utilized for commercial purpose in industries and in household's purpose in homes. A research study shows, natural gas enterprise purchasing surplus renewable energy from wind farms and implements a $\mathrm{P} 2 \mathrm{G}$ unit, through gas pipelines from storage tanks the gas is conveyed to the demand centers [8]. In [9], the elementary equipment in the installation of power to gas to power i.e. fuel cell and hydrogen generator and the storage of energy in the form of hydrogen gas are deliberated. The efficiency of the load is improved for consideration and $\mathrm{P} 2 \mathrm{G}$ system is integrated with renewable energy sources. With the cumulative load, the efficiency reduced in the process (conversion, electrolyzer and fuel cell stack) of the examined power range (30\% to $100 \%)$. Cost ratio of trade and buying of electricity was examined and enhanced which is economically viable and proficient. Fig. 2 shows the model of power to gas installation.

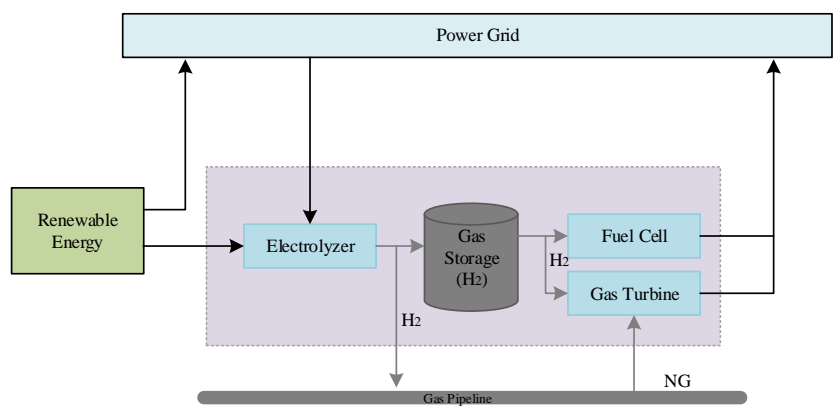

Fig. 2. Model of Power to Gas Installation.

Power to gas system can rise the usage of power generation from renewable energy sources and can store surplus energy. The stored methane gas took from $\mathrm{P} 2 \mathrm{G}$ system can be utilize for commercial, industrial and power generation [10], [11]. $\mathrm{P} 2 \mathrm{G}$ system solving the issues of $\mathrm{CO}_{2}$ and energy storage and the scholars forecasts the data for 2025 energy storage. The statistics for demo-plants schemes has usual costs of around one million euro per year [12], [13]. High temperature coelectrolyser $\left(600-850^{\circ} \mathrm{C}\right)$ and structure catalyst $\left(450-600^{\circ} \mathrm{C}\right)$ in methanation sections are analysed with various aspects for power to gas storage system [14]. In Europe, 2\% hydrogen concentration is permissible to be mixed with natural gas and then injected to pipeline (natural gas). According to the predictive analysis for 2020 the surplus electrical energy generated from renewable sources will reach to $40 \mathrm{MW}$ and $45 \mathrm{GW}$ h per year and that is the most favorable to develop the power to gas capacity [15].

\section{Siting of the System}

For planning of any system proper location is important and power to gas also need an appropriate location for installation. As $\mathrm{P} 2 \mathrm{G}$ is the conversion of electricity to gas from renewable energy sources so hydro, solar and wind are the best choices. The accessibility of carbon dioxide $\left(\mathrm{CO}_{2}\right)$ gas setup and renewable energy sources are diverse conditions for the assortment of installation and ideal site for $\mathrm{P} 2 \mathrm{G}$ system. The installation of $\mathrm{P} 2 \mathrm{G}$ system is safe, consistent and effective in the designated region. The study shows the selected site (Saxony-Anhalt Germany) is the best choice for P2G installation and the system's budget decrease for installation and operation, reducing the losses of $\mathrm{P} 2 \mathrm{G}$ system are the deliberated objectives of the technology to profit the country [16]. In [17], [18], Long-term optimization model is studied whose target is to minimize the cost by selecting the proper location, capacity and time period of installation. In [19], a model is used which integrates marketoriented modeling of interconnected networks. Which is effective and manageable for large systems.

\section{Essential AsPect Of IES WITH P2G PlanNING}

\section{A. Coupling of IES with P2G System}

The indication of power to gas gives an option for an economically consistent system. To install this system in reality, coupling of IES with $\mathrm{P} 2 \mathrm{G}$ system is important. A research study showed the optimal planning approach of integrated energy system and reports the contests of future renewable energy sources conquered energy systems, the system model is associated with outmoded energy setups and the coupling of power to gas and other energy systems using conversion technologies [20]. Vigorous integrated improvement plans for electricity and natural gas systems, considering the obscurity effect of demand growth and hydrology limits. This shows that integrated study endures for good resolve of the insignificant and cost-effective prosperities that are generated by installed apparatuses in the system [21].

For refining the power grid elasticity in severe situations an integrated electricity and natural gas transport system planning algorithm was presented. An inconstant vagueness set is recognized to label the associations between power grid improvement circumstances and extreme occasions and the in effect technique to upsurge the power grid flexibility [22]. Due to pecuniary and environmental reparations of natural gas associated to fossil fuels, its integration with the power system is taken an important place. The study indicates that a 
mixed-integer linear multistage optimization problem diminishes the expenditures of operation [23], [24]. In [25], the new nodal generation provisions, new transmission lines, and natural gas pipelines are promptly added in a multi-period planning vision, which has resolved the large scale mixed integer non-linear problem. In [24], [26], the study delivers a modeling approach for combined coordination and astonishment in electricity and natural gas demand progression. In [25], [27], For large scale systems for transmission expansion planning (TEP), natural gas grid expansion planning (NGGEP) and generation expansion planning (GEP), a multi-period integrated method is deliberated.

The indecisions embrace short run uncertainties such as irregular supply availability from renewable generators or long run indecisions such as approach or ability differences. The study demonstrates a model reduces the investment budget of gas-fired generators, natural gas channels and the operation charges of the natural gas-fired supply generators over a long-term planning scene [28]. The design model of electricity and natural gas systems indicates that demand vagueness carries a precise technique, mainly for efficacies that need to reflect varied extension approaches in diverse cost-effective circumstances that effect power and natural gas consumption. Consequences show that a little price outcome can be achieved that is accomplished to supply dissimilar states of power and natural gas consumption [26]. Ref [29], demonstrates demand indecision and expansion planning which outcomes illustrates the low-cost result of gas and power consumption. In [30], the optimization technique is used for convex modeling of power and gas system. In [31], optimizes asset under indecision by stochastic generation expansion planning. The study illustrates expansion planning for generation, transmission and natural gas grid issues for large-scale systems [27].

\section{B. Aims of IES with P2G Planning}

The integrated energy system is playing a vigorous part in the energy sector. As the usage of renewable energy is increasing, the energy sector is gradually varying for improved efficiency in the system. The IES with P2G is appreciated research which is very significant for decreasing radiation and increase the technologies to decrease the prices and welfares the public. The gas production from electricity is by performing water electrolysis method, and the produced gas can be utilize for different purposes such as, in homes for heating and cooking, as a fuel for the conveyance system and also can regenerate electricity. From water electrolysis, we can develop hydrogen and oxygen gases, hydrogen can be utilize for many purposes e.g. in generation and transportation system and oxygen can release to the atmosphere, or give it to hospital.

The features of IES with $\mathrm{P} 2 \mathrm{G}$ expansion give us many opportunities in single system. The power to gas system is an auspicious choice for a long lasting storage system of generating electricity from renewable energy sources. The power to gas system can develop system elasticity and can integrate, the electrical system with other energy systems [32]. The power to gas system could perform an imperative part in the enhancement of high efficiency and elasticity of integrated energy systems. It can swiftly transform the integrated energy system to sustainability and the produced gas (hydrogen) can boost the growth of fuel cell vehicles market [6].

\section{Applications of the System}

The scheme of power to gas system is eco-friendly which will show a significant role in refining the atmosphere. There are numerous applications of IES with P2G system as this is a coupled system of electricity and gas system. The power side applications emphasis on generation, transmission, distribution, and utilization and the gas side applications are concerning towards generation, transmission, distribution, storage, and utilization. P2G system take many applications in different areas, such as industries, conveyance and energy distribution which study cost-effective and eco-friendly welfares [33].

IES with $\mathrm{P} 2 \mathrm{G}$ system is a very applicable system for the improvement of the economy. Integrated organization and ultimate operation of electricity and gas transmission arrangements is the preeminent application of IES with P2G system. P2G system abides additional energy systems to link with the electrical system and offer elasticity to the electrical system [32]. A study demonstrates, the application of advanced energy storage systems are economically superlative and can reduce the price in the electrical system. In some situations, the applications of storage caused in a growth in fuel utilization and emissions [34].

\section{Economic Analysis of the System}

The energy arcade assists as an association which integrates heating, conveyance and power sectors with each other in P2G system. Economically the link of hydrogen and methane use in the transport sector and the reconversion to power are studied in this reference paper [2]. P2G can increasingly subsidize to reduce the vagueness of dispatch centers and can accomplish a significant role in balancing the power grid. Different cost-effective charges are examined for the ideal magnitude of the system estimated generation, predicting faults and load circumstances are statistically used. The cost-effective hybrid system is the preeminent choice in performance comprising complementary technologies [35], [36]. A research study indicates, a macroeconomic investigation predictive statistics of $\mathrm{P} 2 \mathrm{G}$ system costcovering operation is not possible until 2030. The plants could be cost-effective in 2040 and can attain full load hours in the future energy system [37].

The integrated energy system is sparingly valuable for microgrid strategy, consumer, energy sources, education, and national grid arrangement [38]. The research study showed to investigate substitute generation development and the approach examined economically to assess the possessions of PV uncertainties, renewable energy goals, gas prices, carbon prices, and load growth [39]. In [40], Newton's and Interior point technique was used for resolving hybrid technique of optimal power flow for integrated electricity and gas system. In [41], Convex optimization technique is used for steadystate transient IES simulation tools. In [31], a study shows an random generation expansion planning method which increases investment decisions under uncertain environment to offer a safe system. In [42], according to the prognostic investigation in the year $205080 \%$ of electricity mandate will 
be attained from renewable energy sources which need bulky scale energy storage and $\mathrm{P} 2 \mathrm{G}$ system is preeminent option to handle this objective. For a mandate supply of the power plant price reducing generation, the plan is defined through market simulation methodology that's are generation units, electricity demand, and fuel prices.

Natural gas prices imitates transport cost of natural gas flow course which is not effective economically. The joined operation of natural gas and electrical system optimization is inclined by the limits used. The optimal dispatch of natural gas and electricity system incorporation and decoupling consequences are associated and examined [43]. In [44], an approach dual decomposition, Lagrangian relaxation, and dynamic programming are used to reduce the operation cost of the integrated gas-electricity system.

\section{CONCLUSION}

This paper reviewed integrated energy system with power to gas technology, to describe the contribution of integrated energy system with power to gas system. Based on IES-P2G study different analysis regarding recent published research work are reviewed. A review covering all the relevant research of IES with power to gas system including modeling, P2G conversion technologies, basics, storage capacity and siting are reviewed. The essential aspects, coupling, aims, applications and economic analysis are discussed.

The process of converting surplus electrical energy into gases by water electrolysis, and its planning for different purposes in the integrated energy system is essential for promoting and developing the IES-P2G technology. The conventional power system will be replaced by $\mathrm{P} 2 \mathrm{G}$ system in future and therefore it is expected to be revolutionary and environmental friendly technology. The recent development in technologies of integrated energy system with power to gas system are discussed with proper references.

Modeling of IES-P2G system to boost the operation performance of the system, stabilize the system and compromise better services to consumers are studied and investigated. The Storage capacity of gases after conversion from electricity to gases, are reviewed of an integrated energy system with the power to gas technology. The storage capacity depends on the availability of power to gas production and installed rated power system generation. Economic analysis and siting are discussed to provide future facilities and analyze the problems. To economize the system different renewable energy options are investigated for proper location and the closer availability of the system to consumers are the better options to economize the system which are under research and will take a decade or more to get optimal results. P2G need further research work in future to analyze the problems of cost reduction, optimal location, economy, energy efficiency improvement and appropriate methodologies for integration.

\section{ACKNOWLEDGMENT}

There is no funding for this work and the author is very thankful to teachers, friends and everyone for their help, support and guidance. Special thanks to parents and siblings for their encouragement and support.

\section{REFERENCES}

[1] J. Fang, J. Wen, Q. Zeng, X. Ai, and Z. Chen, "Dynamic Optimal Energy Flow in the Integrated Natural Gas and Electrical Power Systems," IEEE Trans. Sustain. Energy, vol. 9, no. 1, pp. 188-198, 2017.

[2] S. Schiebahn, T. Grube, M. Robinius, V. Tietze, B. Kumar, and D. Stolten, "Power to Gas: Technological Overview, Systems Analysis and Economic Assessment for a Case Study in Germany," Int. J. Hydrogen Energy, vol. 40, no. 12, pp. 4285-4294, 2015.

[3] G. Reiter, "Power-to-Gas," First Edit., Wiley-VCH Verlag GmbH \& Co.KGaA, 2016, pp. 357-368.

[4] Stephen Clegg and Pierluigi Mancarella, "Integrated Modelling and Assessment of the Operational Impact of Power-to-Gas (P2G) on Electrical and Gas Transmission Networks," IEEE Trans. Sustain. Energy, vol. 6, no. 4, pp. 1234-1244, 2015.

[5] Y. Li, W. Liu, M. Shahidehpour, F. Wen, K. Wang, and Y. Huang, "Optimal Operation Strategy for Integrated Natural Gas Generating Unit and Power-to-Gas Conversion Facilities," IEEE Trans. Sustain. Energy, vol. 9, no. 4, pp. 1870-1879, 2018.

[6] A. Lewandowska-Bernat and U. Desideri, "Opportunities of Powerto-Gas Technology,” Energy Procedia, vol. 105, pp. 4569-4574, 2017.

[7] H. F. and Q. C. J. Liu, H. Zhong, K. Zeng, "Optimal Scheduling of Multiple Energy System Considering Power to Gas Unit," in 2017 IEEE Conference on Energy Internet and Energy System Integration (EI2), Beijing, 2017, pp. 1-6.

[8] J. H. Huang, H. S. Zhou, Q. H. Wu, S. W. Tang, B. Hua, and X. X. Zhou, "Assessment of an Integrated Energy System Embedded with Power-to-Gas Plant," IEEE PES Innov. Smart Grid Technol. Conf. Eur., pp. 196-201, 2016.

[9] J. Kotowicz, D. Węcel, and M. Jurczyk, "Analysis of Component Operation in Power-to-Gas-to-Power Installations," Appl. Energy, vol. 216, no. September 2017, pp. 45-59, 2018.

[10] J. Vandewalle, K. Bruninx, and W. D'Haeseleer, "Effects of LargeScale Power to Gas Conversion on the Power, Gas and Carbon Sectors and their Interactions," Energy Convers. Manag., vol. 94, pp. 28-39, 2015.

[11] M. Jentsch, T. Trost, and M. Sterner, "Optimal Use of Power-to-Gas Energy Storage Systems in an 85\% Renewable Energy Scenario," Energy Procedia, vol. 46, pp. 254-261, 2014.

[12] D. M. O. Esteybar, R. G. Rubio-Barros, and A. Vargas, "Large Storage Facilities Valuation in Integrated Planning of Natural Gas and Power Systems," 2016 IEEE PES Transm. Distrib. Conf. Expo. Am. PES T D-LA 2016, 2017.

[13] M. Bailera, P. Lisbona, L. M. Romeo, and S. Espatolero, "Power to Gas Projects Review: Lab, Pilot and Demo Plants for Storing Renewable Energy and CO2," Renew. Sustain. Energy Rev., vol. 69, no. January 2016, pp. 292-312, 2017.

[14] M. A. Ancona et al., "Thermal integration of a high-temperature coelectrolyzer and experimental methanator for Power-to-Gas energy storage system," Energy Convers. Manag., vol. 186, no. March, pp. 140-155, 2019.

[15] B. Simonis and M. Newborough, "Sizing and Operating Power-to-Gas Systems to Absorb Excess Renewable Electricity," Int. J. Hydrogen Energy, vol. 42, no. 34, pp. 21635-21647, 2017.

[16] N. Moskalenko, P. Lombardi, and P. Komarnicki, "Multi-Criteria Optimization for Determining Installation Locations for the Power-toGas Technologies," IEEE Power Energy Soc. Gen. Meet., vol. 2014Octob, no. October, pp. 1-5, 2014.

[17] Q. Zeng, J. Fang, Z. Chen, J. Li, and B. Zhang, "A Multistage Coordinative Optimization for Sitting and Sizing P2G Plants in an Integrated Electricity and Natural Gas System," 2016 IEEE Int. Energy Conf. ENERGYCON 2016, pp. 0-5, 2016.

[18] B. Odetayo, J. Maccormack, W. D. Rosehart, and H. Zareipour, "Integrated Planning of Natural Gas and Electricity Distribution Networks with the Presence of Distributed Natural Gas Fired Generators," IEEE Power Energy Soc. Gen. Meet., vol. 2016-Novem, 2016.

[19] S. Hecq, Y. Bouffioulx, P. Doulliez, and P. Saintes, "The Integrated Planning of the Natural Gas and Electricity Systems Under Market Conditions," 2001 IEEE Porto Power Tech Proc., vol. 1, pp. 467-471, 2001.

[20] I. Van Beuzekom, M. Gibescu, P. Pinson, and J. G. Slootweg, "Optimal Planning of Integrated Multi-Energy Systems," 2017 IEEE Manchester PowerTech, Powertech 2017, vol. 1, 2017.

[21] C. A. Saldarriaga-Cortes, H. Salazar, R. Moreno, and G. JimenezEstevez, "Integrated Planning of Electricity and Natural Gas Systems Under Uncertain Hydro Inflows: A Multi-Objetive Approach," IEEE Power Energy Soc. Gen. Meet., vol. 2017-Janua, pp. 1-5, 2017. 
[22] C. Shao, M. Shahidehpour, X. Wang, X. Wang, and B. Wang, "Integrated Planning of Electricity and Natural Gas Transportation Systems for Enhancing the Power Grid Resilience," IEEE Trans. Power Syst., vol. 32, no. 6, pp. 4418-4429, 2017.

[23] I. J. Perez-Arriaga, A. C. Z. de Souza, C. Unsihuay-Vila, P. P. Balestrassi, and J. W. Marangon-Lima, "A Model to Long-Term, Multiarea, Multistage and Integrated Expansion Planning of Electricity and Natural Gas Systems," IEEE Trans. Power Syst., vol. 25, no. 2, pp. 1154-1168, 2010.

[24] B. Odetayo, M. Kazemi, J. MacCormack, W. D. Rosehart, H. Zareipour, and A. R. Seifi, "A Chance Constrained Programming Approach to the Integrated Planning of Electric Power Generation, Natural Gas Network and Storage," IEEE Trans. Power Syst., vol. 33 , no. 6, pp. 6883-6893, 2018.

[25] F. Barati, H. Seifi, A. Nateghi, M. S. Sepasian, M. Shafie-Khah, and J. P. S. Catalão, "An Integrated Generation, Transmission and Natural Gas Grid Expansion Planning Approach for Large Scale Systems," IEEE Power Energy Soc. Gen. Meet., vol. 2015-Septe, pp. 1-5, 2015.

[26] A. J. C. and R. S. B. Zhao, "Coordinated Expansion Planning of Natural Gas and Electric Power System," IEEE Trans. Power Syst. vol. 33, no. 3, pp. 3064-3075, 2018.

[27] F. Barati, M. S. Sepasian, M. Shafie-khah, J. P. S. Catalao, A. Nateghi, and H. Seifi, "Multi-Period Integrated Framework of Generation, Transmission and Natural Gas Grid Expansion Planning for LargeScale Systems," IEEE Trans. Power Syst., vol. 30, no. 5, pp. $2527-$ 2537, 2014.

[28] B. Odetayo, J. MacCormack, W. D. Rosehart, and H. Zareipour, “A Chance Constrained Programming Approach to Integrated Planning of Distributed Power Generation and Natural Gas Network," Electr. Power Syst. Res., vol. 151, pp. 197-207, 2017.

[29] C. A. Saldarriaga, R. A. Hincapie, and H. Salazar, "An Integrated Expansion Planning Model of Electric and Natural Gas Distribution Systems Considering Demand Uncertainty," IEEE Power Energy Soc. Gen. Meet., vol. 2015-Septe, no. 978, 2015.

[30] C. Borraz-Sánchez, R. Bent, S. Backhaus, S. Blumsack, H. Hijazi, and P. Van Hentenryck, "Convex Optimization for Joint Expansion Planning of Natural Gas and Power Systems," Proc. Annu. Hawaii Int. Conf. Syst. Sci., vol. 2016-March, pp. 2536-2545, 2016.

[31] N. Van Bracht and A. Moser, "Generation Expansion Planning Under Uncertainty Considering Power-to-Gas Technology," Int. Conf. Eur. Energy Mark. EEM, 2017.

[32] A. Mazza, E. Bompard, and G. Chicco, "Applications of Power to Gas Technologies in Emerging Electrical Systems," Renew. Sustain. Energy Rev., vol. 92, no. January 2017, pp. 794-806, 2018.

[33] S. S. Al-zakwani, A. Maroufmashat, A. Mazouz, M. Fowler, and A. Elkamel, "Allocation of Ontario's Surplus Electricity to Different Power to Gas Applications," energies, no. 2017, 2019.

[34] H. S. de Boer, L. Grond, H. Moll, and R. Benders, "The Application of Power-to-Gas, Pumped Hydro Storage and Compressed Air Energy Storage in an Electricity System at Different Wind Power Penetration Levels," Energy, vol. 72, pp. 360-370, 2014.

[35] J. Qiu et al., "Multi-Stage Flexible Expansion Co-Planning Under Uncertainties in a Combined Electricity and Gas Market," IEEE Trans. Power Syst., vol. 30, no. 4, pp. 2119-2129, 2015.

[36] G. Guandalini, S. Campanari, and M. C. Romano, "Power-to-Gas Plants and Gas Turbines for Improved Wind Energy Dispatchability: Energy and Economic Assessment," Appl. Energy, vol. 147, pp. 117130, 2015.

[37] R. C. McKenna et al., "The Future Role of Power-to-Gas in the Energy Transition: Regional and Local Techno-Economic Analyses in Baden-Württemberg," Appl. Energy, vol. 212, no. November 2017 , pp. 386-400, 2018.

[38] D. Cartes, J. Ordonez, J. Harrington, D. Cox, and R. Meeker, "Novel Integrated Energy Systems and Control Methods with Economic Analysis for Integrated Community Based Energy Systems," 2007 IEEE Power Eng. Soc. Gen. Meet. PES, vol. 32310, pp. 1-6, 2007.

[39] T. K. S. and D. C. J. B. Nunes, N. Mahmoudi, "Generation Expansion Planning in Queensland Under Rooftop Photovoltaic Penetration and Gas Market Uncertainties," in 2015 IEEE PES Asia-Pacific Power and Energy Engineering Conference (APPEEC), Brisbane,QLD, 2015, pp. $1-5$.

[40] C. Unsihuay, J. W. M. Lima, and A. C. Z. De Souza, "Modeling the Integrated Natural Gas and Electricity Optimal Power Flow," 2007 IEEE Power Eng. Soc. Gen. Meet. PES, pp. 1-7, 2007.

[41] Z. Wei, S. Chen, H. Zang, G. Sun, and D. Wang, "Steady State and Transient Simulation for Electricity-Gas Integrated Energy Systems by Using Convex Optimisation," IET Gener. Transm. Distrib., vol. 12, no. 9, pp. 2199-2206, 2018.

[42] I. Marjanovic, T. Bongers, J. Lichtinghagen, and A. Moser, "Influence of Power-to-Gas-Technology on Unit Commitment and Power
System Operation," 2017 6th Int. Conf. Clean Electr. Power Renew. Energy Resour. Impact, ICCEP 2017, pp. 536-540, 2017.

[43] D. M. Ojeda-Esteybar, R. G. Rubio-Barros, O. Ano, and A. Vargas, "Integration of Electricity and Natural Gas Systems-Identification of Coordinating Parameters," 2014 IEEE PES Transm. Distrib. Conf. Expo. PES T D-LA 2014 - Conf. Proc., vol. 2014-Octob, 2014.

[44] C. Unsihuay, J. W. Marangon-Lima, and A. C. Zambroni De Souza, "Short-Term Operation Planning of Integrated Hydrothermal and Natural Gas Systems," 2007 IEEE Lausanne POWERTECH, Proc. pp. 1410-1416, 2007. 